\title{
Solutions to conserve the vase life of Heliconia 'Tropics'
}

\author{
Gisela Carrera Alvarado ${ }^{1} \mathbb{D}$; Obdulia Baltazar-Bernal ${ }^{1 \mathbb{D}}$ \\ 'Colegio de Postgraduados, Campus Córdoba. Carretera Federal Córdoba-Veracruz km 348, Congregación Manuel León. 94946, municipio \\ de Amatlán de los Reyes, Ver., México; carrera.gisela@colpos.mx; obduliabb@colpos.mx (author for correspondence)
}

\begin{abstract}
Heliconia 'Tropics' has high market acceptance and blooms year-round. Still, there is little information on solutions to prolong its vase life. The objective of this research was to assess pulse solutions to prolong the vase life of Heliconia 'Tropics' in three cutting stages. Floral stems in a closed, semi-open and commercial grown stages from three years old plants grown in an outdoor setting were evaluated. Three experiments were evaluated: sucrose at 10 , 20 and $30 \%(\mathrm{w} / \mathrm{v})$; Hydraflor ${ }^{\circledR} 100$ at $0.25,0.50$ and $0.75 \mathrm{~g} \mathrm{~L}^{-1}$; and citric acid (CA) at 25, 50, 100, 150 and $200 \mathrm{ppm}$, and a control (tap water). The floral opening, fresh weight of the floral stems, solution consumption and vase life were measured every two days. Based on the best results of these experiments, the following combinations were assessed: $10 \%$ sucrose $+0.50 \mathrm{~g} \mathrm{~L}^{-1}$ Hydraflor ${ }^{\circledR} 100 ; 10 \%$ sucrose $+150 \mathrm{ppm} \mathrm{CA} ; 10 \%$ sucrose $+0.50 \mathrm{~g} \mathrm{~L}^{-1}$ Hydraflor $^{\circledR} 100$ +150 ppm CA; $0.50 \mathrm{~g} \mathrm{~L}^{-1}$ of Hydraflor ${ }^{\circledR} 100+150$ ppm CA and a control. A $10 \%$ sucrose $+0.50 \mathrm{~g} \mathrm{~L}^{-1}$ of Hydraflor ${ }^{\circledR} 100$ pulse for 24 $\mathrm{h}$ had a 22.8-day vase life and was superior to the floral stems in the control treatment (15.6 days) at the semi-open cut stage. This was associated with greater water consumption, lower fresh weight loss and greater floral opening.
\end{abstract}

Keywords: Heliconia psittacorum x H. spathocircinata, tropical flowers, sucrose, Hydraflor ${ }^{\circledR} 100$, citric acid, pulse solution.

\section{RESUMO}

\section{Soluções para conservar a vida de Heliconia 'Tropics' em vaso}

Heliconia 'Tropics' tem boa aceitação no mercado e floresce o ano todo. Mesmo assim, há poucas informações sobre soluções para prolongar sua vida de vaso. O objetivo desta pesquisa foi avaliar soluções conservantes para prolongar a vida de vaso de Heliconia 'Tropics' em três estágios de corte. Foram avaliados caules florais em estágios de flores fechadas, semiabertas e comerciais de plantas de três anos, cultivadas em ambiente aberto. Foram avaliados três experimentos: sacarose a 10, 20 e $30 \%(\mathrm{p} / \mathrm{v})$; Hydraflor ${ }^{\circledR} 100$ a 0,25 , 0,50 e $0,75 \mathrm{~g} \mathrm{~L}^{-1}$; e ácido cítrico (CA) a 25, 50, 100, 150 e 200 ppm, e um controle (água de torneira). A abertura floral, a massa fresca dos caules florais, o consumo de solução e a vida de vaso foram medidos a cada dois dias. Baseado nos melhores resultados desses experimentos, as seguintes combinações foram avaliadas: $10 \%$ sacarose $+0,50 \mathrm{~g}$ $\mathrm{L}^{-1}$ de Hydraflor ${ }^{\circledR} 100 ; 10 \%$ de sacarose +150 ppm CA; $10 \%$ de sacarose $+0,50 \mathrm{~g} \mathrm{~L}^{-1}$ de Hydraflor ${ }^{\circledR} 100+150 \mathrm{ppm} \mathrm{CA} ; 0,50 \mathrm{~g} \mathrm{~L}^{-1}$ de Hydraflor ${ }^{\circledR} 100+150$ ppm CA e um controle. Sacarose a $10 \%+$ $0,50 \mathrm{~g} \mathrm{~L}^{-1}$ de Hydraflor ${ }^{\circledR} 100$ conservantes por $24 \mathrm{~h}$ resultou em vida de vaso de 22,8 dias e foi superior às hastes florais do tratamento controle (15,6 dias) na fase de corte semiaberto. Isso foi associado ao maior consumo de água, menor perda de massa fresca e maior abertura floral.

Palavras-chave: Heliconia psittacorum x H. spathocircinata, flores tropicais, sacarose, Hydraflor ${ }^{\circledR} 100$, ácido citrico, solução para vaso.

Received on July 24, 2020; accepted on April 29, 2021

I $\mathrm{n}$ cut flowers, quality is closely related to pre- and post-harvest handling. During postharvest, the plant's handling and their postharvest process, as well as inadequate storage conditions can result in excessive loss of these products, flowers or inflorescences. It is estimated that 30 to $40 \%$ of the total flower production is lost due to inadequate postharvest handling (Yadav et al., 2014). In addition, the differentiated quality of the floricultural production defines the destination of the commercialization, either for the internal, or external market destined to exports. Consequently, in Mexico, only a low percentage of production is exported (20\%) and the rest is used to cover the prosperous domestic market (AIPH, 2017).

Reid (2009) states that maintaining good quality in cut flowers depends on the stored nutrients within the stems, leaves and petals; where carbohydrates are the main energy source for inflorescences, for the biochemical and physiological processes during the postharvest life (Halevy \& Mayak, 1978).

The quality of some tropical cut flowers can be maintained and extended with hydration treatments (Folha et al., 2016) or pulsing after harvest (Costa et al., 2015; Baltazar-Bernal \& ZavalaRuíz, 2016). Pulsing is a treatment that loads tissues with high sucrose concentrations with a biocide, a weak acid, an anti-ethylene agent and/or a phytoregulator, generally before their commercialization in national or export markets (Halevy et al., 1978) to increase vase life.

Sucrose is an additional source of the carbohydrates consumed by respiration (Morais et al., 2015; Dias, 2016); it favors water flow and minerals in the xylem and acts on the stomatal closure, thus reducing water loss through transpiration, in addition, accumulates in floral tissues, increases its osmotic concentration and maintains turgor (Halevy et al., 1978), which justifies 
the positive effect on the vase life; furthermore, its application has been reported to influence harvested flowers opening in a closed cut state (Reid, 2009).

The pulsing has been successfully tested on various tropical flowers: in Alpinia purpurata a $2 \%$ sucrose + citric acid (CA) pulse is recommended (Mattiuz et al., 2005); in Polianthes tuberosa a vase solution of $450 \mathrm{ppm}$ of CA maintains the stem's quality by preventing microorganisms growth in the vase solution due to $\mathrm{pH}$ reduction (Jowkar \& Salehi, 2005). In Gardenia jasminoides, $200 \mathrm{ppm}$ of CA increases vase life (Çelikel et al., 2020); in Zingiber spectabile Hydraflor ${ }^{\circledR} 100$ $\left(16 \mathrm{~mL} \mathrm{~L}^{-1}\right)$ improves vase life and stem quality (Coelho et al., 2012).

Within the heliconia family, Heliconia 'Tropics' (Heliconia psittacorum $\mathrm{x}$ H. spathocircinata) is a cut flower that has a great ornamental acceptance by consumers, due to its attractive color, inflorescence size, flowering throughout the year and easy packing since its bracts are arranged in a single plane (Baltazar et al., 2011; Costa et al., 2015). Heliconia 'Tropics' replaces the "bird of paradise" flowers in the Mexican market, and along with its demand, the area sown with this cultivar in Mexico is increasing.

Due to the increase in the planted area with Heliconia 'Tropics' because of its demand is pertinent to investigate: the pulsing with different solutions accessible to small producers to prolong the flower's vase life.

The objective here was to determine the effects of a pulsing treatment that allows prolonging the vase life of Heliconia 'Tropics' using sucrose, Hydraflor ${ }^{\circledR} 100$ and CA, by themselves and in combination at three cut-off points.

\section{MATERIAL AND METHODS}

The research took place from November 2015 to March 2016, at the Colegio de Postgraduados, Campus Córdoba facilities, state of Veracruz, Mexico (18 51'21'”N, 96 51'35'W, $647 \mathrm{~m}$ altitude); its climate is Am, warm humid with abundant rains in summer, with $22^{\circ} \mathrm{C}$ annual mean temperature, $28^{\circ} \mathrm{C}$ mean maximum and $16^{\circ} \mathrm{C}$ mean minimum; $1,800 \mathrm{~mm}$ mean annual precipitation, from May to October the precipitation exceeds 60 $\mathrm{mm}$, and the average relative humidity is $62 \%$ (García, 2005). Heliconia 'Tropics' (Heliconia psittacorum x $H$. spathocircinata) flower stems were used, grown outdoors for three years, at three cut stages: closed, semi-open (one open bract) and commercial (two open bracts) (Figure 1), harvested before 8:00 $\mathrm{AM}$ in the ornamental horticulture area.

The research consisted of five experiments: during the first, the effect of a pulse of 0 (tap water with $\mathrm{pH} 7.1$ and $0.4 \mathrm{mmho} / \mathrm{cm} \mathrm{EC),} \mathrm{10,} 20$ and $30 \%$ $(\mathrm{w} / \mathrm{v})$ sucrose for $24 \mathrm{~h}$; in the second experiment, the effect of a Hydraflor ${ }^{\circledR}$ 100 from Floralife ${ }^{\circledR}$, Walterboro, USA, preservative solution at concentrations of 0 (tap water), $0.25,0.50$ and $0.75 \mathrm{~g}$ $\mathrm{L}^{-1} \mathrm{pH} 7.1,5.5,4.2$ and 3.9 respectively were evaluated; in the third, the effect of a preservative solution of CA at 0 (tap water), 25, 50, 100, 150 and $200 \mathrm{ppm}$ with $\mathrm{pH}$ 7.1, 6.7, 6.4, 5.8, 5.2 and 4.6 respectively, were evaluated. All three experiments were tested at the three cut-off stages.

Based on the best previous three experiments results, the fourth evaluated experiment was $10 \%$ sucrose +150 ppm CA, $10 \%$ sucrose $+0.50 \mathrm{~g} \mathrm{~L}^{-1}$ Hydraflor ${ }^{\circledR} 100,10 \%$ sucrose +0.50 $\mathrm{g} \mathrm{L}^{-1}$ Hydraflor ${ }^{\circledR} 100+150 \mathrm{ppm}$ CA, $0.50 \mathrm{~g} \mathrm{~L}^{-1}$ Hydraflor ${ }^{\circledR} 100+150$ ppm CA and tap water at the semiopen and commercial cut-off points (Figures 1B and 1C, respectively). The fifth experiment evaluated the effect of pulsing $10 \%$ sucrose $+0.50 \mathrm{~g} \mathrm{~L}^{-1}$ Hydraflor ${ }^{\circledR} 100$ for $0,4,8,12,24$ and 48 hours at the semi-open cut-off stage (Figure 1C).

In all the experiments, the stems were set to $80 \mathrm{~cm}$ in length and were kept in a room at $22^{\circ} \mathrm{C} \pm 2,57 \mu \mathrm{mol} \mathrm{m}^{-2} \mathrm{~s}^{-1}$ of light and $75 \% \mathrm{RH}$. Temperature, relative humidity, and light were recorded using external automatic recording equipment, Onset HOBO brand, model U12-012. The evaluated variables were:

Fresh weight loss: fresh weight of the flower stems were evaluated every two days, with a digital scale, until the end of their vase life. The fresh weight loss calculation was reported as the total fresh weight loss at 14 days of vase life (VL) and was expressed in $g$ of fresh weight.

Floral opening: evaluated every two days and up to 14 days of VL during the experiment, the distance at the maximum width of the open bracts was measured and reported as the difference in the initial and final floral opening in $\mathrm{cm}$.

Water consumption: the volume of the vase liquid solution was recorded every two days and up to 14 days during the VL (accounting for the water loss by evapotranspiration) and recorded as water consumed in $\mathrm{mL}$.

Vase life (VL): measured as the number of days from the cut-off date to the day when at least one of the following symptoms appeared: necrosis in a bract, bract wilting, bending of the stem.

\section{Statistical analysis}

A completely randomized experimental design was used, with a factorial arrangement in the structure of the treatments. In the first four experiments, the factors were the harvest stages and the solution concentrations. In each treatment of the five experiments, eight repetitions were used, each flower stem as an experimental unit. The obtained data were analyzed using an analysis of variance (ANOVA) and a Tukey mean comparison test $(\alpha=0.05)$, with the $\mathrm{SAS} \otimes 9.4$ statistical package software (2012).

\section{RESULTS AND DISCUSSION}

\section{Experiment 1 - Effect of pulsing with sucrose}

The flower stems from the three cut stages developed no new bracts, even with a pulsed treatment at a high concentration (30\%). However, a significant effect $(P=0.0216)$ of the pulsing was observed on the floral opening of the inflorescences at the semi-open cutting point. The flower stems with an open bract (semi-open cut-off point), pulsed with $20 \%$ sucrose, had the greatest opening difference $(6.75$ 
$\mathrm{cm}$ ), followed by those pulsed with 10 and $30 \%$ sucrose from the same cutting point. Sucrose pulsing has been used for several years in roses, carnations and later in bird of paradise (Strelitzia reginae) flowers (Halevy et al., 1978) to maintain the sugar level of the stems, as sucrose is the substrate for respiration, and in this way, guarantee the floral opening is closed cut points (De la Cruz et al., 2007; Reid, 2009).

Several studies have shown changes in the sugar levels in the flowers at the time of opening. These changes particularly consist in sugars reduction, such as glucose and fructose in peony (Xiang-Feng et al., 2009), and Fresia (Shu et al., 2010). That is, the role of sugars in promoting flower opening, which explains higher opening values in pulsed inflorescences.

Regarding the loss of fresh weight in the flower stems, a clear trend in the treatments is not observed either, the closed or commercial cut-off points, but the sucrose at $20 \%$ concentration generated the greatest loss of fresh weight at the semi-open cut point (Table 1). In regard to water consumption, it was significantly lower in non-pulsed flower stems $(P=0.0001)$ than in pulsed ones with 20 and $30 \%$ sucrose at all cutoff points. In the three cut-off points, the sucrose concentration that generated the highest water consumption was $20 \%$. The highest solution consumption occurred during the first four days (Figure 2).

The interaction between the cutoff point and pulsing solution had a significant effect $(P=0.0001)$ on the vase life of the inflorescences in the closed/semi-open cut-off points with a $10 \%$ sucrose pulsing (Table 1). The longest vase life was found with the $10 \%$ sucrose pulsing, with a VL of 25.6, 25.4 and 24.3, which increased by 2, 4.2 and 3.6 days in the closed, semi-open and commercial cut-off points, respectively, compared with the VL of the non-pulsed stems (Table 1).

Reid (2009) mentions that adding a carbohydrates source, such as sucrose, to vase solutions, results in an extension of the vase life if the microorganism's growth is controlled. Therefore, according to this author, the vase life increase of heliconia in acid solutions is due to the inhibition of vascular blockage by microorganisms and increased water absorption.

\section{Experiment 2 - Hydration with} Hydraflor $^{\circledR} 100$
The stems treated with Hydraflor $\AA$ 100 showed similar behavior to those treated with sucrose; that is, there was no new bracts development at any cut point. Hydraflor ${ }^{\circledR} 100$ and the interaction cut-off point and Hydraflor ${ }^{\circledR} 100$ had a significant effect $P=0.0001$ and $P=$

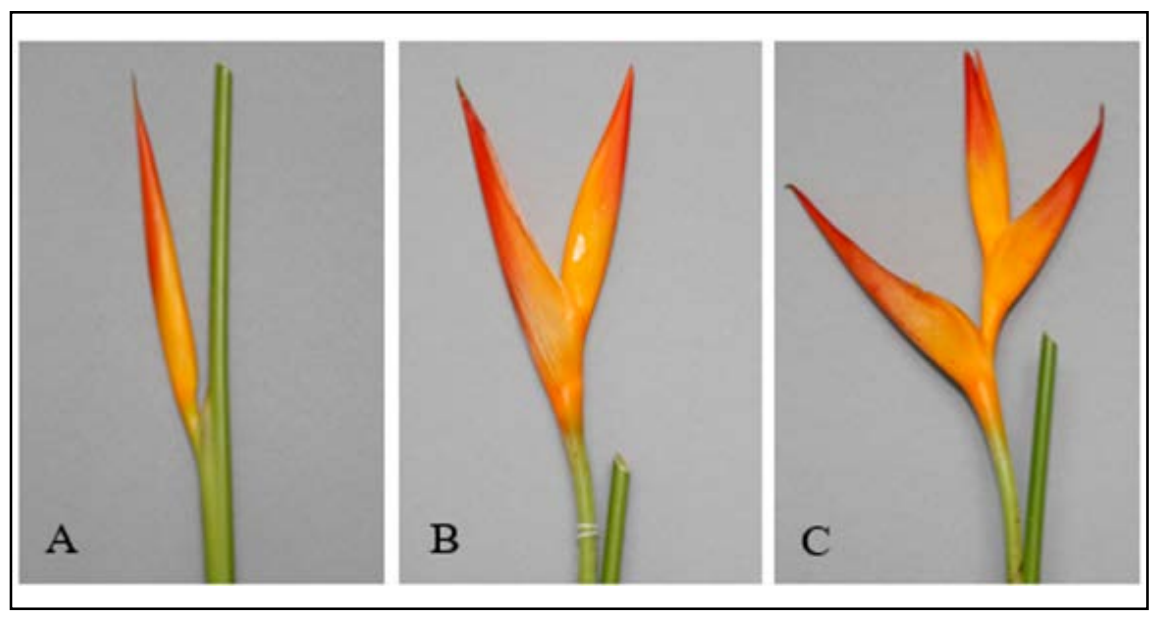

Figure 1. Heliconia 'Tropics' (H. psittacorum $\mathrm{x}$ H. spathocircinata) cutting stages: A) closed, B) semi-open, and C) commercial. Veracruz, Mexico, Colegio de Postgraduados, Campus Córdoba, 2016.

Table 1. Means comparison of four measured variables in floral stems of Heliconia 'Tropics' (H. psittacorum $\mathrm{x}$ H. spathocircinata) pulsed for $24 \mathrm{~h}$ with different concentrations of sucrose, evaluated at day 14 of their vase life. Veracruz, Mexico, Colegio de Postgraduados, Campus Córdoba, 2016.

\begin{tabular}{|c|c|c|c|c|c|}
\hline Cut stage & $\begin{array}{c}\text { Sucrose } \\
(\%)\end{array}$ & $\begin{array}{c}\text { Floral } \\
\text { opening } \\
(\mathbf{c m}) \\
\end{array}$ & $\begin{array}{c}\text { Fresh } \\
\text { weight } \\
\text { loss (g) }\end{array}$ & $\begin{array}{c}\text { Water } \\
\text { consumption } \\
(\mathbf{m L}) \\
\end{array}$ & $\begin{array}{c}\text { Vase life } \\
\text { (days) }\end{array}$ \\
\hline \multirow{4}{*}{ Closed } & 0 & 0 & $8.19^{b}$ & $47.25^{f}$ & $23.63^{\text {bcd }}$ \\
\hline & 10 & 0 & $9.43^{\mathrm{ab}}$ & $48.25^{\mathrm{ef}}$ & $25.63^{\mathrm{a}}$ \\
\hline & 20 & 0 & $9.70^{\mathrm{ab}}$ & $54.88^{\mathrm{cd}}$ & $23.38^{\mathrm{cd}}$ \\
\hline & 30 & 0 & $11.37^{\mathrm{ab}}$ & $51.88^{\text {de }}$ & $23.50^{\mathrm{cd}}$ \\
\hline \multirow{4}{*}{ Semi-open } & 0 & $2.53^{\mathrm{bcd}}$ & $9.09^{\mathrm{b}}$ & $48.50^{\mathrm{ef}}$ & $21.13^{\mathrm{e}}$ \\
\hline & 10 & $4.62^{\mathrm{ab}}$ & $9.35^{b}$ & $55.50^{\mathrm{cd}}$ & $25.38^{\mathrm{ab}}$ \\
\hline & 20 & $6.75^{\mathrm{a}}$ & $12.81^{\mathrm{a}}$ & $65.63^{a}$ & $25.00^{\mathrm{abc}}$ \\
\hline & 30 & $4.46^{\mathrm{bc}}$ & $9.18^{b}$ & $52.13^{\text {de }}$ & $24.25^{\mathrm{a}}$ \\
\hline \multirow{4}{*}{ Commercial } & 0 & $1.60^{\mathrm{d}}$ & $9.61^{\mathrm{ab}}$ & $54.00^{\text {cd }}$ & $20.75^{\mathrm{e}}$ \\
\hline & 10 & $0.93^{\mathrm{d}}$ & $10.32^{\mathrm{ab}}$ & $56.37^{\mathrm{cd}}$ & $24.38^{\mathrm{abcd}}$ \\
\hline & 20 & $2.31^{\mathrm{cd}}$ & $9.12^{\mathrm{b}}$ & $61.75^{\mathrm{ab}}$ & $24.25^{\mathrm{abcd}}$ \\
\hline & 30 & $1.25^{\mathrm{d}}$ & $10.54^{\mathrm{ab}}$ & $58.50^{\mathrm{bc}}$ & $23.13^{\mathrm{d}}$ \\
\hline CV (\%) & & 0.93 & 0.35 & 0.13 & 0.09 \\
\hline \multicolumn{6}{|c|}{ Significance $(p \leq 0.05)$} \\
\hline $\mathrm{CS}$ & & 0.0001 & 0.8867 & 0.0001 & 0.0453 \\
\hline Sucrose & & 0.0216 & 0.4029 & 0.0001 & 0.0001 \\
\hline CS x Sucrose & & 0.1506 & 0.3004 & 0.0109 & 0.0073 \\
\hline
\end{tabular}

Means with the same letter between columns are not statistically different. Tukey, $P<0.05$. 
Table 2. Means comparison of four variables measured in floral stems of Heliconia 'Tropics' (H. psittacorum $\mathrm{x}$ H. spathocircinata) treated with different concentrations of Hydraflor ${ }^{\circledR}$ 100 , evaluated at day 14 of their vase life. Veracruz, Mexico, Colegio de Postgraduados, Campus Córdoba, 2016.

\begin{tabular}{|c|c|c|c|c|c|}
\hline Cut stage & $\begin{array}{c}\text { Hydraflor }{ }^{\circledR} \\
100\left(\mathrm{~g} \mathrm{~L}^{-1}\right)\end{array}$ & $\begin{array}{l}\text { Floral } \\
\text { opening } \\
(\mathrm{cm})\end{array}$ & $\begin{array}{c}\text { Fresh } \\
\text { weight loss } \\
\text { (g) }\end{array}$ & $\begin{array}{c}\text { Water } \\
\text { consumption } \\
(\mathrm{mL})\end{array}$ & $\begin{array}{l}\text { Vase life } \\
\text { (days) }\end{array}$ \\
\hline \multirow{4}{*}{ Closed } & 0.00 & 0.00 & $5.46^{\mathrm{bc}}$ & $37.50^{\mathrm{fg}}$ & $18.00^{\text {bcd }}$ \\
\hline & 0.25 & 0.00 & $3.46^{\mathrm{efg}}$ & $48.13^{\mathrm{bc}}$ & $17.50^{\text {cde }}$ \\
\hline & 0.50 & 0.00 & $2.58^{\mathrm{g}}$ & $55.00^{\mathrm{a}}$ & $19.75^{\mathrm{ab}}$ \\
\hline & 0.75 & 0.00 & $0.92^{\mathrm{h}}$ & $38.88^{\mathrm{fg}}$ & $19.25^{\mathrm{abc}}$ \\
\hline \multirow{4}{*}{ Semi-open } & 0.00 & $3.41^{\mathrm{ab}}$ & $6.34^{\mathrm{b}}$ & $36.00^{\mathrm{g}}$ & $16.50^{\operatorname{def}}$ \\
\hline & 0.25 & $3.15^{\mathrm{ab}}$ & $4.58^{\text {cdef }}$ & $40.75^{\mathrm{ef}}$ & $16.50^{\text {def }}$ \\
\hline & 0.50 & $2.10^{\mathrm{bc}}$ & $0.94^{\mathrm{h}}$ & $43.75^{\text {de }}$ & $20.50^{\mathrm{a}}$ \\
\hline & 0.75 & $0.98^{\mathrm{c}}$ & $4.95^{\text {bcde }}$ & $45.00^{\mathrm{bcd}}$ & $15.50^{\text {ef }}$ \\
\hline \multirow{4}{*}{ Commercial } & 0.00 & $0.95^{\mathrm{c}}$ & $8.16^{\mathrm{a}}$ & $31.37^{\mathrm{h}}$ & $15.87^{\text {ef }}$ \\
\hline & 0.25 & $3.95^{\mathrm{a}}$ & $5.08^{\mathrm{bcd}}$ & $44.25^{\text {cde }}$ & $16.50^{\text {def }}$ \\
\hline & 0.50 & $1.44^{\mathrm{c}}$ & $3.79^{\operatorname{defg}}$ & $48.63^{\mathrm{b}}$ & $18.25^{\mathrm{bcd}}$ \\
\hline & 0.75 & $1.50^{\mathrm{c}}$ & $3.23^{\mathrm{fg}}$ & $41.25^{\text {def }}$ & $15.75^{\text {ef }}$ \\
\hline CV (\%) & & 0.83 & 0.62 & 0.18 & 0.14 \\
\hline \multicolumn{6}{|c|}{ Significance $(p \leq 0.05)$} \\
\hline $\mathrm{CS}$ & & 0.0896 & 0.0001 & 0.0014 & 0.0004 \\
\hline \multicolumn{2}{|c|}{ Hydraflor ${ }^{\circledR} 100$} & 0.0001 & 0.0001 & 0.0001 & 0.0001 \\
\hline \multicolumn{2}{|c|}{ CS x Hydraflor ${ }^{\circledR} 100$} & 0.0002 & 0.0001 & 0.0001 & 0.0935 \\
\hline
\end{tabular}

Means with the same letter between columns are not statistically different. Tukey, $P<0.05$.

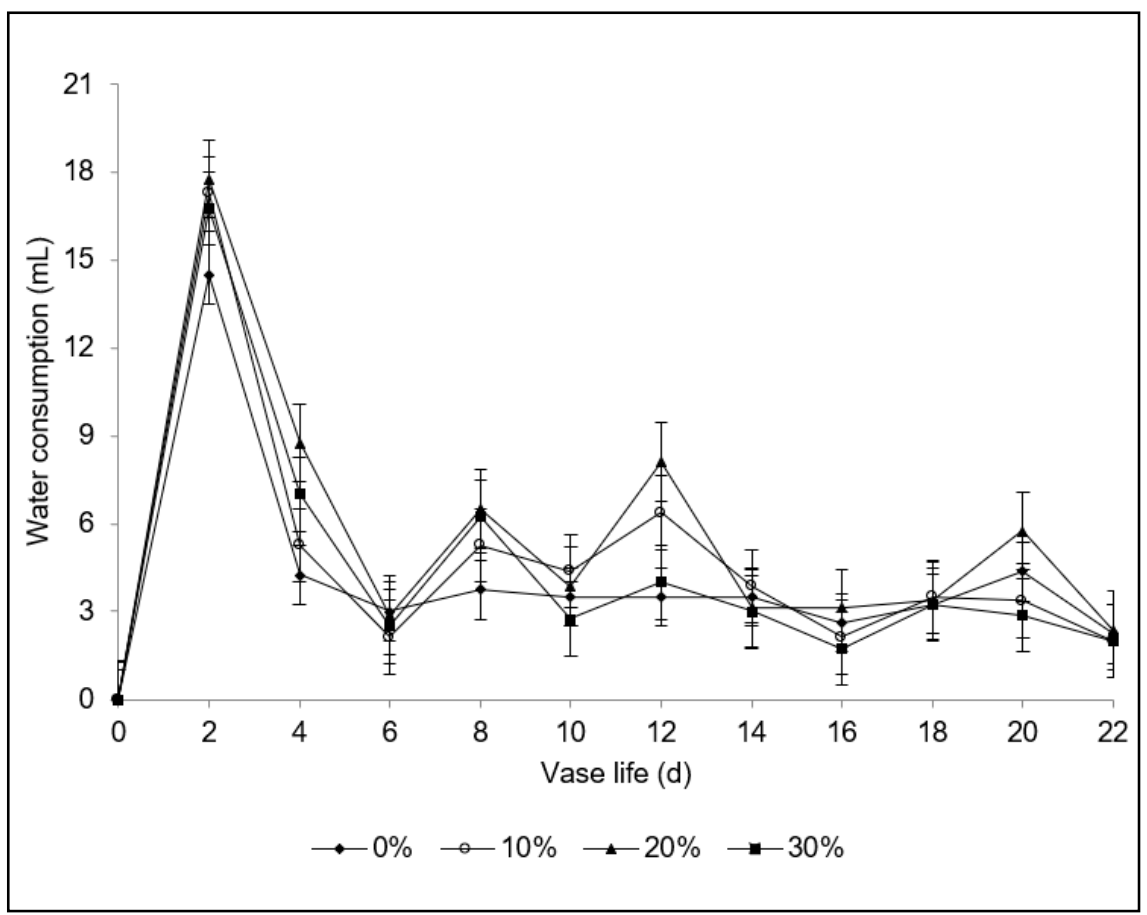

Figure 2. Water consumption during postharvest life of Heliconia 'Tropics' (H. psittacorum $\mathrm{x} H$. spathocircinata) in a semi-open stage pulsed with sucrose at $0,10,20$ and $30 \%(\mathrm{p} / \mathrm{v})$. Veracruz, Mexico, Colegio de Postgraduados, Campus Córdoba, 2016.
0.0002 each, on the difference in floral opening of the already opened bracts. At the semi-open cut-off point, the higher the Hydraflor ${ }^{\circledR} 100$ concentration in the vase solution, the smaller the difference in the floral opening; therefore, the control presented the largest opening $(3.41 \mathrm{~cm})$; while, in the stems at the commercial stage, the opening difference was greater in those treated with Hydraflor ${ }^{\circledR} 100$ compared to the stems of the control treatment $\left(0 \mathrm{~g} \mathrm{~L}^{-1}\right)$, which were of $0.95 \mathrm{~cm}$ (Table 2).

The application of sucrose or Hydraflor ${ }^{\circledR} 100$ in the vase solution, despite contributing to the opening of the already opened bracts, did not allow to increase the number of bracts in the inflorescences of Heliconia 'Tropics'. Costa et al. (2011) and Carrera-Alvarado et al. (2020) stated that the opening of floral bracts in heliconia flowers is disabled once the plant's stem is separated. Contrary to that in the bird of paradise flowers (Strelitzia reginae), which opens its buds even when harvested in a closed point and has greater longevity, compared to those harvested when the first bract begins to open (Dias, 2016).

Regarding the loss of fresh weight, it had a significant effect $(P \leq 0.0001)$ on the cut points of the flower stems, the Hydraflor ${ }^{\circledR} 100$ concentration and the interaction (Table 2). On the treatments, the fresh weight loss of the flower stems was significantly higher $(P=0.0001)$ in the control treatment $\left(0 \mathrm{~g} \mathrm{~L}^{-1}\right)$, compared to that of the stems treated with Hydraflor ${ }^{\circledR} 100$, in the three cutting points. At the highly closed cut-off point, the control lost $7.85 \%$ of the fresh weight of the floral stem, while with $0.75 \mathrm{~g} \mathrm{~L}^{-1}$ Hydraflor ${ }^{\circledR} 100$ only $1.08 \%$ was lost. At the semi-open cut-off point, the control treatment $(0 \mathrm{~g}$ $\left.\mathrm{L}^{-1}\right)$ lost $8.42 \%$ of the fresh weight of the floral stem, while with $0.50 \mathrm{~g} \mathrm{~L}^{-1}$ Hydraflor ${ }^{\circledR} 100$, only $0.42 \%$ of the fresh weight was lost. In this same stage, the flower stems treated with Hydraflor ${ }^{\circledR}$ 100 increased their fresh weight, unlike the control treatment, in which, after the second day of VL, the fresh weight decreased (Figure 3). In the flowers at the commercial cut-off point, the control $\left(0 \mathrm{~g} \mathrm{~L}^{-1}\right)$ lost $10.0 \%$ of its fresh weight 
Table 3. Means comparison of four variables assessed in floral stems of Heliconia 'Tropics' (H. psittacorum $\mathrm{x}$ H. spathocircinata) pulsed with four different solutions and a control (tap water) for $48 \mathrm{~h}$, evaluated at day 14 of their vase life. Veracruz, Mexico, Colegio de Postgraduados, Campus Córdoba, 2016.

\begin{tabular}{|c|c|c|c|c|c|}
\hline Cut stage & Treatment & $\begin{array}{c}\text { Floral } \\
\text { opening } \\
\text { (cm) }\end{array}$ & $\begin{array}{c}\text { Fresh } \\
\text { weight loss } \\
\text { (g) }\end{array}$ & $\begin{array}{c}\text { Water } \\
\text { consumption } \\
(\mathrm{mL})\end{array}$ & $\begin{array}{c}\text { Vase } \\
\text { life } \\
\text { (days) }\end{array}$ \\
\hline \multirow{5}{*}{ Semi-open } & Control (tap water) & $1.51^{\mathrm{bcd}}$ & $10.59^{\mathrm{abc}}$ & $46.25^{\mathrm{bc}}$ & $19.63^{\mathrm{de}}$ \\
\hline & $\begin{array}{l}10 \% \text { sucrose }+150 \\
\text { ppm CA }\end{array}$ & $1.06^{\text {cde }}$ & $12.07^{\mathrm{ab}}$ & $42.75^{\mathrm{cd}}$ & $21.63^{\mathrm{cd}}$ \\
\hline & $\begin{array}{l}10 \% \text { sucrose }+0.50 \mathrm{~g} \\
\mathrm{~L}^{-1} \text { Hydraflor }{ }^{\circledR} 100\end{array}$ & $3.10^{\mathrm{a}}$ & $6.68^{\mathrm{d}}$ & $54.75^{\mathrm{a}}$ & $27.63^{\mathrm{a}}$ \\
\hline & $\begin{array}{l}10 \% \text { sucrose }+150 \\
\text { ppm CA }+0.50 \mathrm{~g} \\
\mathrm{~L}^{-1} \text { Hydraflor }{ }^{\circledR} 100\end{array}$ & $2.29^{\mathrm{ab}}$ & $9.55^{\mathrm{bc}}$ & $46.88^{b c}$ & $25.50^{\mathrm{ab}}$ \\
\hline & $\begin{array}{l}150 \mathrm{ppm} \mathrm{CA}+0.50 \mathrm{~g} \\
\mathrm{~L}^{-1} \text { Hydraflor }{ }^{\circledR} 100\end{array}$ & $1.78^{\mathrm{bc}}$ & $9.50^{\mathrm{bcd}}$ & $55.75^{\mathrm{a}}$ & $21.88^{\mathrm{cd}}$ \\
\hline \multirow{5}{*}{ Commercial } & Control (tap water) & $0.56^{\mathrm{de}}$ & $11.07^{\mathrm{abc}}$ & $42.38^{\text {cd }}$ & $18.25^{\mathrm{e}}$ \\
\hline & $\begin{array}{l}10 \% \text { sucrose }+150 \\
\text { ppm CA }\end{array}$ & $0.79^{\text {cde }}$ & $13.41^{\mathrm{a}}$ & $40.13^{\mathrm{d}}$ & $24.13^{\mathrm{bc}}$ \\
\hline & $\begin{array}{l}10 \% \text { sucrose }+0.50 \mathrm{~g} \\
\mathrm{~L}^{-1} \text { Hydraflor }{ }^{\circledR} 100\end{array}$ & $0.48^{\mathrm{e}}$ & $9.15^{\mathrm{cd}}$ & $51.75^{\mathrm{ab}}$ & $26.00^{\mathrm{ab}}$ \\
\hline & $\begin{array}{l}10 \% \text { sucrose }+150 \\
\text { ppm CA }+0.50 \mathrm{~g} \\
\mathrm{~L}^{-1} \text { Hydraflor }{ }^{\circledR} 100\end{array}$ & $1.09^{\text {cde }}$ & $11.83^{\mathrm{abc}}$ & $41.25^{\mathrm{cd}}$ & $21.63^{\text {cd }}$ \\
\hline & $\begin{array}{l}150 \mathrm{ppm} \mathrm{AC}+0.50 \mathrm{~g} \\
\mathrm{~L}^{-1} \text { Hydraflor }{ }^{\circledR} 100\end{array}$ & $0.85^{\text {cde }}$ & $11.31^{\mathrm{abc}}$ & $44.75^{\mathrm{cd}}$ & $20.00^{\mathrm{de}}$ \\
\hline CV (\%) & & 0.93 & 0.30 & 0.16 & 0.16 \\
\hline \multicolumn{6}{|c|}{ Significance $(\mathrm{p} \leq 0.05)$} \\
\hline CS & & 0.0001 & 0.0112 & 0.0002 & 0.0082 \\
\hline Treatment & & 0.0667 & 0.0005 & 0.0001 & 0.0001 \\
\hline CS x Treatm & ent & 0.0250 & 0.8728 & 0.2636 & 0.0015 \\
\hline
\end{tabular}

Means with the same letter between columns are not statistically different. Tukey, $P<0.05$.

of the floral stems, while with $0.75 \mathrm{~g} \mathrm{~L}^{-1}$ Hydraflor ${ }^{\circledR} 100$ treatment only $4.60 \%$ was lost.

The interaction between the cut-off point and the Hydraflor ${ }^{\circledR} 100$ pulse had a significant effect $(P=0.0001)$, thus the water consumption was higher in the stems treated with Hydraflor ${ }^{\circledR}$ 100 , especially those in a $0.50 \mathrm{~g} \mathrm{~L}^{-1}$ concentration, consuming up to 17 $\mathrm{mL}$ more than the stems in the control treatment $\left(0 \mathrm{~g} \mathrm{~L}^{-1}\right)$, in stems at a closed and commercial cut point and up to $7 \mathrm{~mL}$ more in the stems at a semiopen cut point. Therefore, hydration with Hydraflor ${ }^{\circledR} 100$ to $0.50 \mathrm{~g} \mathrm{~L}^{-1}$ is an optimal concentration for water consumption in the three cut-off points. The longest vase life was observed this effect, water must be acidified to extend vase life (Baltazar-Bernal \& Zavala-Ruiz, 2012; Coelho et al., 2012). At the same time, acidifying the solution allows the metabolic activity in the stem to be maintained, which is associated with higher water consumption. Furthermore, low pH has been reported with a reduction in phenolic oxidation (Halevy et al., 1978; Sardinha et al., 2019) and a decrease in bacterial growth, which delay xylem disruption (Jowkar \& Salehi, 2005). However, no significant differences were obtained in the interaction cutoff point and Hydraflor ${ }^{\circledR}$ 100, which concurs with Lessa et al. (2015) who report that tap water was sufficient to maintain the vase life of Zingiber spectabile.

\section{Experiment 3- Citric acid effect}

No significant effects $(P=0.9428)$ of the citric acid were observed on the vase life of cut stems in a closed development stage, unlike the stems in semi-open and commercial cut-off stages, where the longest vase life was recorded in stems treated with a 150 ppm CA (22.6 and 21.4 days respectively), increasing, in both cases, 4.6 days the vase life compared to stems treated with $0 \mathrm{ppm}$ CA (data not shown).

In experiments 1, 2 and 3, no great influence of the pulsing or preservative solutions was observed on the vase life of the closed cut-off flowers; since the flower stems of the control treatment also showed a long vase life (18 to 23 days). This result is probably due to: 1 ) being in an early development stage, the floral surface exposed to transpiration is smaller than that of the inflorescences of the semi-open and commercial cut stages where the bracts are already open; 2) in the closed stage of development, endogenous sugar levels are high, since it has been shown that the development and opening are associated with overall high levels of reducing sugars, while senescence is associated with low levels (Sane \& Khan, 2013), so exogenous application of sugars is unnecessary. the fact that the solution with the fact that the solution with moisturizer has lower $\mathrm{pH}$ (5.5, 4.2 and 3.9) than tap water (7.4). According to Reid (2009), water frequently contains minerals that turn it alkaline (high $\mathrm{pH}$ ), which drastically reduces its movement within the stems, so that to counteract
Experiment 4 - Evaluation of solutions for pulsing

In Table 3, results show that in flower stems in a semi-open cutting stage the largest opening $(3.10 \mathrm{~cm})$ is obtained 


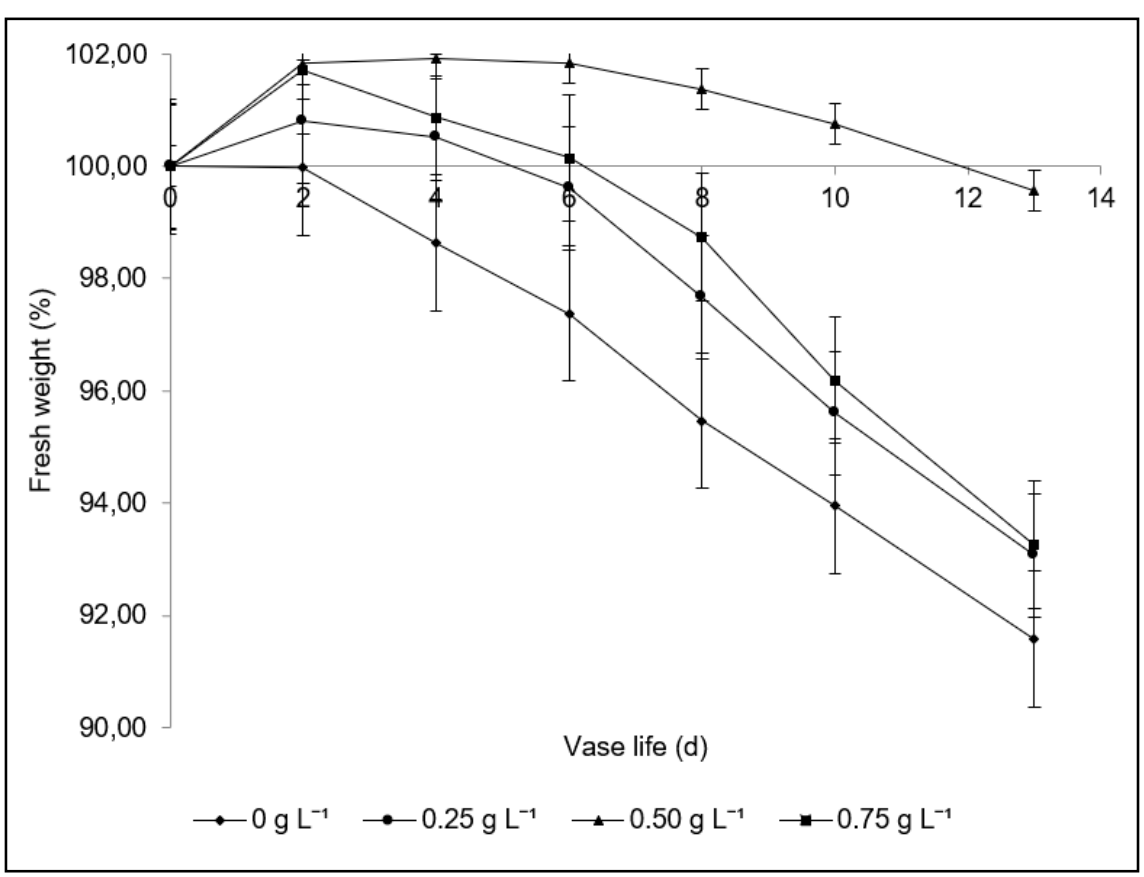

Figure 3. Changes on fresh weight during postharvest life of Heliconia 'Tropics' ( $H$. psittacorum $x H$. spathocircinata) in semi-open stage treated with Hydraflor ${ }^{\circledR} 100$ at $0,0.25$, 0.50 and $0.75 \mathrm{~g} \mathrm{~L}^{-1}$. Veracruz, Mexico, Colegio de Postgraduados, Campus Córdoba, 2016.

Table 4. Means comparison of four variables measured in floral stems of Heliconia 'Tropics' (H. psittacorum $\times$ H. spathocircinata) pulsed with $10 \%$ sucrose $+0.50 \mathrm{~g} \mathrm{~L}^{-1}$ Hydraflor ${ }^{\circledR}$ 100 at different times, evaluated on day 14 of their vase life. Veracruz, Mexico, Colegio de Postgraduados, Campus Córdoba, 2016.

\begin{tabular}{lcccc}
\hline Pulse time (h) & $\begin{array}{c}\text { Floral } \\
\text { opening } \\
(\mathbf{c m})\end{array}$ & $\begin{array}{c}\text { Fresh } \\
\text { weight loss } \\
(\mathbf{g})\end{array}$ & $\begin{array}{c}\text { Water } \\
\text { consumption } \\
(\mathbf{m L})\end{array}$ & $\begin{array}{c}\text { Vase life } \\
(\mathbf{d a y s})\end{array}$ \\
\hline 0 & $1.92^{\mathrm{b}}$ & $27.84^{\mathrm{a}}$ & $45.17^{\mathrm{e}}$ & $15.67^{\mathrm{d}}$ \\
4 & $4.60^{\mathrm{a}}$ & $15.21^{\mathrm{b}}$ & $46.17^{\mathrm{de}}$ & $17.33^{\mathrm{cd}}$ \\
8 & $3.33 \mathrm{~b}^{\mathrm{a}}$ & $14.00^{\mathrm{b}}$ & $49.50^{\mathrm{cd}}$ & $17.33^{\mathrm{cd}}$ \\
12 & $3.43 \mathrm{~b}^{\mathrm{a}}$ & $12.07^{\mathrm{b}}$ & $56.17^{\mathrm{a}}$ & $19.5 \mathrm{~b}^{\mathrm{c}}$ \\
24 & $2.93 \mathrm{~b}^{\mathrm{a}}$ & $9.22^{\mathrm{b}}$ & $52.50^{\mathrm{bc}}$ & $22.83^{\mathrm{a}}$ \\
48 & $2.93 \mathrm{~b}^{\mathrm{a}}$ & $13.87^{\mathrm{b}}$ & $53.80^{\mathrm{ab}}$ & $21.67^{\mathrm{ba}}$ \\
\hline CV $(\%)$ & 0.56 & 0.60 & 0.09 & 0.17 \\
Significance $(\mathrm{p} \leq 0.05)$ & & & \\
Pulse time & 0.2740 & 0.0178 & 0.0001 & 0.0007 \\
\hline Means with the same letter between columns are not statistically different. Tukey, $P<0.05$
\end{tabular}

with the pulsing of $10 \%$ sucrose +0.50 $\mathrm{g} \mathrm{L}^{-1}$ Hydraflor ${ }^{\circledR} 100,1.59 \mathrm{~cm}$ more than the control treatment $(P=0.0250)$. The flower stems in a commercial cut stage showed less bract opening than that stems with a semi-open cut stage. The treatment that reported the highest result $(0.53 \mathrm{~cm}$ more than the control) was that with $10 \%$ sucrose +150 ppm CA +0.50 $\mathrm{g} \mathrm{L}^{-1}$ Hydraflor ${ }^{\circledR} 100$. In the two cutoff points (semi-open and commercial) control treatment (tap water). Therefore, the sucrose effect was enhanced with Hydraflor ${ }^{\circledR} 100$.

In previous experiments, longer vase life was associated with higher water consumption and lower weight loss as the result of using sucrose and Hydraflor ${ }^{\circledR} 100$, by itself or in combination in the vase solution. Given that, during the vase life of the stems pulsed with sucrose, there was a higher water consumption than that of the nonpulsed stems (Figure 2); and the flower stems treated with Hydraflor ${ }^{\circledR} 100$ increased their fresh weight during the first three days, unlike the stems of the control treatment (Figure 3). Halevy \& Mayak (1981) reported that the flowers that maintain or increase their weight, achieve a longer vase life than those in which the weight decrease. Sucrose has been reported to improve the water balance in cut flowers, by regulating their osmotic potential and the water retention capacity of their tissues, which may explain the weight and vase life increased (Reid, 2009; Sane \& Khan, 2013). In cut flowers of Rosa cv. Royalty, longer vase life was associated with higher water consumption, along with slow loss of fresh weight (De la Cruz et al., 2007), as well as in heliconia inflorescences (Mangave et al., 2014; Patel et al., 2017).

\section{Experiment 5 - Evaluation of pulsing with $10 \%$ sucrose $+0.50 \mathrm{G} \mathrm{I}^{-1}$ hydraflor ${ }^{\circledR} 100$}

The pulsing time had no significant effect on the floral opening of the control treatment but had a significant effect on the fresh weight loss $(P \leq 0.0178)$, water consumption $(P \leq 0.0001)$ and vase life $(P \leq 0.0007)$. The flower stems pulsed for 12 hours had a higher water consumption $(56.17 \mathrm{~mL})$, followed by the stems pulsed for 48 hours $(53.80 \mathrm{~mL})$ and 24 hours $(52.50 \mathrm{~mL})$. Regarding the VL of Heliconia 'Tropics' stems pulsed for 24 hours with $10 \%$ sucrose $+0.50 \mathrm{~g}$ $\mathrm{L}^{-1}$ Hydraflor ${ }^{\circledR} 100$, it increased up to 7.1 days more than non-pulsed stems (15.6 days), that is, it reached a vase life of 22.8 days (Table 4 ).

Pulsing with $10 \%$ sucrose +0.50 $\mathrm{g} \mathrm{L}^{-1}$ Hydraflor ${ }^{\circledR} 100$ significantly increased the vase life of Heliconia 
'Tropics', by conserving the metabolic activity of the stems, which facilitated the maintenance of water absorption and its flow. This was probably caused by sucrose, slightly reducing the osmotic potential, and Hydraflor ${ }^{\circledR} 100$ slightly reducing the solution's $\mathrm{pH}$. This concurs with Halevy et al. (1978), who reported that in bird of paradise flowers (Strelitzia reginae) vase life increased up to 8 days by pulsing with $10 \%$ sucrose + $50 \mathrm{ppm}$ of $\mathrm{AgNO}_{3}$ and $150 \mathrm{ppm} \mathrm{CA}$ for $24 \mathrm{~h}$. Asrar (2012) also reported that a $2 \%$ sucrose +200 ppm 8-HQS pulse in snapdragon cut flowers resulted in longer vase life because the pulse played a fundamental role in promoting water absorption and in the metabolic processes of flower stems. Likewise, in Heliconia Golden Torch, a spray with $100 \mathrm{mg} \mathrm{L}^{-1} \mathrm{GA}$ and $50 \mathrm{mg} \mathrm{L}^{-1}$ bovine serum albumin improved vase life, and was associated with increased fresh weight and water absorption (Mangave et al., 2013). In Heliconia wagneriana, a $10 \%$ sucrose pulsing for 60 minutes maintained the quality of the inflorescences 20\% longer than in control stems that had high transpiration and low water consumption (Costa et al., 2015). In Oncidium varicosum orchids a $5 \%$ sucrose $+100 \mathrm{mg} \mathrm{L}^{-1} 8-\mathrm{HQC}$ $+50 \mathrm{mg} \mathrm{L}^{-1} \mathrm{AgNO}_{3}$ vase solution maintained the relative water content and the carbohydrates and soluble sugars content in the flowers, thus preserving the vase life for longer compared to stems of a control treatment (Mattiuz et al., 2015).

According to the results here presented, it can be concluded that all the used solutions increased the vase life of Heliconia 'Tropics'; however, the $10 \%$ sucrose $+0.50 \mathrm{~g} \mathrm{~L}^{-1}$ Hydraflor $\AA$ 100 pulsing for 24 hours maintained the vase life for 22.8 days. This is associated with greater water absorption, greater floral opening, and less fresh weight loss. This solution maintained the metabolic activity of the stems, which provided and maintained the water flow. This was possibly caused by the sucrose solution that slightly reduces osmotic potential, associated with a slight decrease in $\mathrm{pH}$ caused by Hydraflor $\AA$ 100. Therefore, this treatment has potential as a preservative solution for cut flowers of Heliconia 'Tropics' in a semi-open cut stage.

\section{REFERENCES}

AIPH, 2017. The international statistics flowers and plants yearbook. In: The international statistics flowers and plants yearbook. Hannover: Institut für Gartenbauökonomie.

ASRAR, AWA. 2012. Effects of some preservative solutions on vase life and keeping quality of snapdragon (Antirrhinum majus L.) cut flowers. Journal of the Saudi Society of Agricultural Sciences 11: 29-35, https://doi. org/10.1016/j.jssas.2011.06.002

BALTAZAR-BERNAL, O; ZAVALA-RUIZ, J. 2012. Cultivo de maracas (Zingiber spp.) en la floricultura tropical. AGROProductividad 5: 20-28.

BALTAZAR-BERNAL, O; ZAVALA-RUIZ, J. 2016. Flores tropicales de corte. Colegio de Postgraduados. Texcoco, Edo. de México. 89p.

BALTAZAR-BERNAL, O; ZAVALA-RUIZ, J; HERNÁNDEZ-NATAREN, SJ. 2011. Producción comercial de heliconias. Colegio de Postgraduados. Texcoco, Edo. de México. 66p.

CARRERA-ALVARADO, G; AREVALOGALARZA, LDM; VELASCO-VELASCO, J; RUIZ-POSADAS, LDM; SALINASRUÍZ, J; BALTAZAR-BERNAL, O. 2020. Postharvest management of Heliconia psittacorum $\times$ H. spathocircinata $\mathrm{cv}$. Tropics. AGROProductividad 13: 99-105.

COELHO, LL; CARNEIRO, DNM; PAIVA, PDO; CARNEIRO, LF. 2012. Soluções conservantes e pulsing na pós-colheita de Zingiber spectabile. Pesquisa Agropecuária Tropical 42: 482-485, https://doi.org/10.1590/ S1983-40632012000400016

CELIKEL, FG; REID, MS; JIANG, CZ. 2020. Postharvest physiology of cut Gardenia jasminoides flowers. Scientia Horticulturae 261: 108983.

COSTA, AS; NOGUEIRA, LC; SANTOS, VF; CAMARA, TR; LOGES, V; WILLADINO L. 2011. Storage of cut Heliconia bihai (L.) cv. Lobster Claw flowers at low temperatures. Revista Brasileira de Engenharia Agrícola e Ambiental 15: 966-972. https://doi. org/10.1590/S1415-43662011000900013

COSTA, LC; COSTA, RR; RIBEIRO, WS; CARNEIRO, GG; BARBOSA, JA; FINGER, FL. 2015. Postharvest longevity of Heliconia wagneriana. Acta Horticulturae 1060: 193-200. https://doi.org/10.17660/ ActaHortic.2015.1060.28

DE LA CRUZ, GGH; ARRIAGA, FA; MANDUJANO, PM; ELIAS, AJB. 2007. Efecto de tres preservadores de la longevidad sobre la vida postcosecha de Rosa cv. Royalty. Revista Chapingo serie Horticultura 13: 109-113. http://www.redalyc.org/articulo. oa? id $=60913115$

DIAS, GM. 2016. Quality maintenance of tropical plants. Ornamental Horticulture 22: 256-258. https://doi.org/10.14295/oh.v22i3.961

FOLHA, WR; SOUZA, RR; AMARAL, GC; SILVA, AA; CARVALHO, JN; CAVALCANTE, MZB. 2016. Heliconia 'Golden Torch' postharvest: stem ends cutting and renewing vase water benefits. Ornamental Horticulture 22: 180-185. https:// doi.org/10.14295/oh.v22i2.908

GARCÍA, E. 2005. Modificación al sistema de clasificación climática de Köppen. $4^{\mathrm{a}}$. Edición. Instituto de Geografía. Universidad Autónoma de México.

HALEVY, AH; KOFRANEK, AM; BESEMER, ST. 1978. Postharvest handling methods for bird of paradise flowers (Strelitzia reginae Ait.). Journal of the American Society for Horticultural Science 103: 165-169. http://agris.fao.org/agris-search/search. do? recordID $=$ US19780318819

HALEVY, AH; MAYAK, S. 1981. Senescence and postharvest physiology of cut flowers. Part 2. Horticultural Reviews 3: 59-143. https://doi. org/10.1002/9781118060766.ch3

JOWKAR, MM; SALEHI, H. 2005. Effects of different preservative solutions on the vase life of cut tuberous flowers at usual home conditions. Acta Horticulturae 669: 411-416. https://doi.org/10.17660/ ActaHortic.2005.669.54

LESSA, MA; ALMEIDA, EFA; NASCIMENTO, AMP; CURVELO, ICS; REIS, SN; NOGUEIRA, DA; PAIVA, PDO. 2015. Postharvest conservation of ornamental ginger (Zingiber spectabile). Acta Horticulturae 1060: 307-313. https://doi: 10.17660/ ActaHortic.2015.1060.46

MANGAVE, BD; SINGH, A; JHA, S; CHAWLA, SL. 2014. Postharvest physiology and quality of heliconia inflorescence cv. Golden Torch as influenced by antioxidants. The Horticultural Society of India 71: 232-236.

MANGAVE, BD; SINGH, A; MAHATMA, M. 2013. Effects of different plant growth regulators and chemicals spray on postharvest physiology and vase life of heliconia inflorescence cv. Golden Torch. Plant Growth Regulation 69: 259-264. https://doi. org/10.1007/s10725-012-9768-1

MATTIUZ, CFM; MATTIUZ, BH; RODRIGUES, TJD; MARQUES, KM; MARTINS, RN. 2015. Effectiveness of postharvest solutions for the conservation of cut Oncidium varicosum (Orchidaceae) inflorescences. Ciência e Agrotecnologia 39: 315-322.

MATTIUZ, CFM; RODRIGUES, TJD; MATTIUZ, BH; PIVETTA, KFL. 2005. Aspectos fisiológicos e qualitativos da conservação pós-colheita de inflorescências de gengibre-vermelho [Alpinia purpurata (vieill.) K. Schum.]. Científica Jaboticabal 33: 83-90. http://cientifica.org.br/index.php/cientifica/ article/view/70/52

MORAIS, MB; SILVA, MMA; HERCULANO, L; CAMARA, TR; WILLADINO, L. 2015. Postharvest senescence of Alpinia floral stems: antioxidative effect of pulsing. Proc. Xth IS on postharvest quality of ornamental plants. Acta Horticulturae 1060: 289-294. https:// doi.org/10.17660/ActaHortic.2015.1060.43

PATEL, UR; PATIL, S; SATHYANARAYANA, E; 
PATEL, VD; PATEL, TD. 2017. Effect of vase solutions on flowers of different varieties of heliconia. International Journal of Chemical Studies 5: 400-402.

REID, MS. 2009. Poscosecha de las flores cortadas, manejo y recomendaciones.
Ediciones Hortitecnia Ltda. Bogotá, Colombia. 36p.

SANE, AP; KHAN, S. 2013. Metabolic shifts in sugars during floral senescence. Stewart Postharvest Review 4: 1-5. https://doi. org/10.2212/spr.2013.4.5
SARDINHA, DHS; RODRIGUES, AAC; RIBEIRO, SSM; DINIZ, NB; NETO, JRMC; OLIVEIRA, RF. 2019. Phytostimulants influence the vase life of Heliconia psittacorum cv. golden torch. Postharvest Biology and Technology 155: 140-148. https://53p. 